\title{
1114 微小流路内における気泡特性評価
}

\author{
Evaluation of bubble characteristics in micro channels \\ O学 山口理知 正 楊 明
}

Noritomo YAMAGUCHI, Ming Yang, Tokyo Metropolitan University, 1-1 Minami-ohsawa, Hachioji-shi,

Tokyo 192-0397, JAPAN

\begin{abstract}
This paper describes evaluation of characteristics of air bubbles in micro channel. Micro channels for generation and separation bubbles ware designed and fabricated. Air bubbles about $50 \mu \mathrm{m}$ in diameter were generated repeatedly , and trapped with micro channel to separate from the water. Air bubbles and flow around bubbles ware visualized using micro-PIV. Removal characteristic of bubbles ware evaluated by Reynolds number and Weber number. Scale effect was appeared while decreasing diameter of bubbles. Bubble energy for unit volume was proposed as the quantity to evaluate the adhesion bubbles and separate from the wall.
\end{abstract}

.Key Words: $\mu$ TAS, Bubble, micro-PIV,

\section{1 緒置}

数十 $\mu \mathrm{m}$ から数百 $\mu \mathrm{m}$ の微小な領域で, 高効率な反态を行う Micro Total analysis System ( $\mu \mathrm{TAS})$, Lab-on-a-chip が注目されるよ うになった. $\mu \mathrm{TAS}$ は, 試薬供給部（ポンプ）, 混合部（ミキサ 一，反応部検出部で構成されており，各構成要素の研究が盛ん に行われている[1]. $\mu \mathrm{TAS} て ゙ は$ 液体を扱うことが多く, 流路内 部に気泡が侵入したとき，送液や検出に悪影響を引き起こすこ とが問題となっている. 現在までに，流路をふさぐような気泡 について研究[2]が行われてきたが，気泡が壁面へ付着した微小 気泡についての研究はなされてない.

本研究では, 微小流路内部における気泡の特性として, 付着 と脱離の評価実験とモデル化を行うことにより, 流路に浸入す

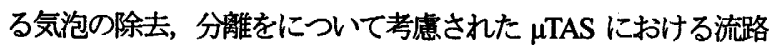
の設計指針を示すこと目的とした。

\section{2 マイクロチャンネルの作製}

\section{1 気泡生成チャンネル設計と評価}

気泡を生成するために，作製したマイクロチャンネルを図 1 に 示寸. ドライエッチングとウェットエッチングによって Si に溝 を加工，外部との接続のために超音波加工によって貫通穴を加 エし, $\mathrm{Si}$ と $\mathrm{SiO}_{2}$ を陽極接合している.

少量のサイズに切り出された気泡を, 液体によって押し出すこ とで微小な気泡を生成した. 手順を図 2 に示す.

(1)気体を送り込み中央の細いチャンネルに気泡充填

(2)両脇から液体を流し，余分な気体を排出

(3)閉じ込められた気体を押し気泡を生成

気泡生成実験および可視化装置を図 3 に示し，生成された気泡 の画像と生成された気泡直径の分布を図 4 に示す. 約直径 $50 \mu \mathrm{m}$ の気泡を繰り返し生成可能にした

\section{2 気泡除去チャンネルの設計と評価}

$\mu \mathrm{TAS}$ などの微小な流路に入り込んだ気泡を, システム外一排 除は困難であることが多い. そこで, 気泡を除去するのではな く, 気泡により悪影響を及ぼさない任意の位置に移動もしくは 捕捉しておけばよいとして, 本研究では, マイクロチャンネル を製作した微小スリットを用いて気泡を捕捉するチャンネル設

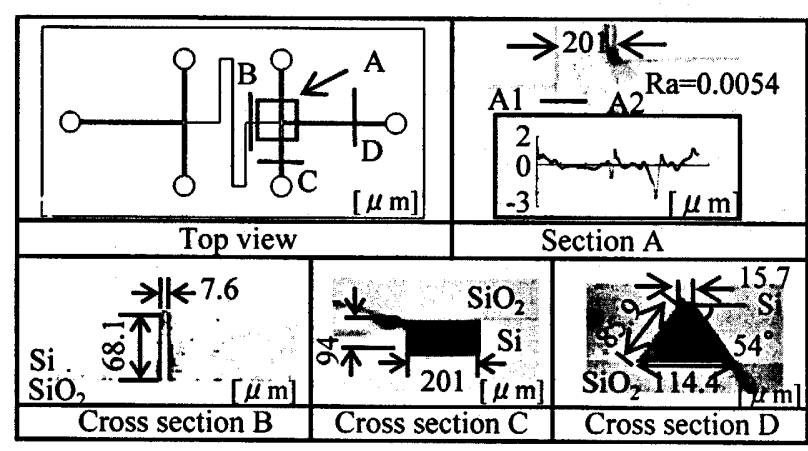

Fig.1 Image and size of Air bubble generation channel

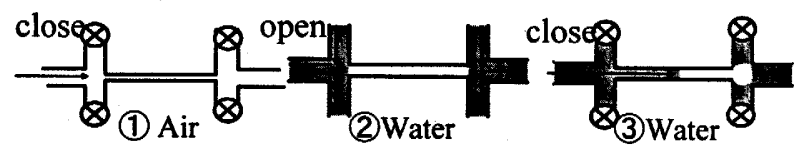

Fig.2 Schematic Procedure of Air bubble generating

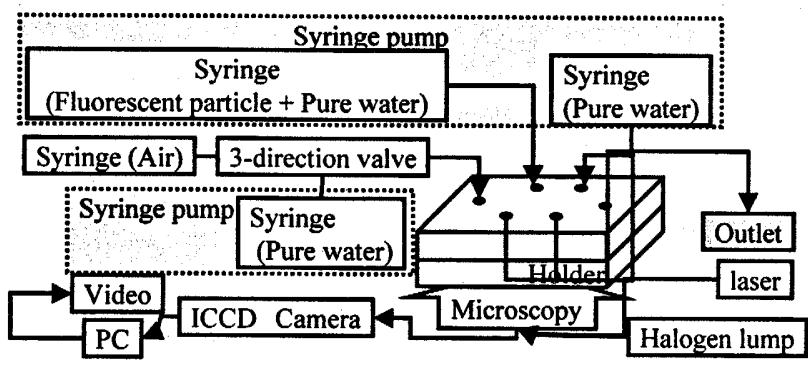

Fig. 3 Experimental setup

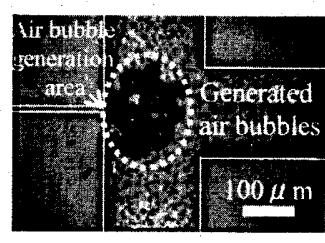

(a) Magnetic Image

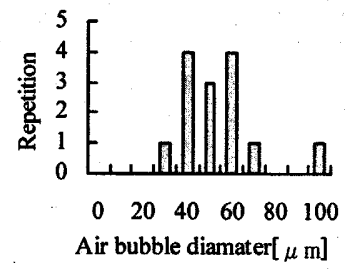

(b) Histograms of generated air bubble diameter
Fig.4 Air bubbles generated by micro channels

日本機械学会 [No.05-6] IIP2005 情報·知能·精密機器部門講演会講演論文集 ['05.3.21,22,東京] 
計した. 概略図を図 5 に寸法を表 1 に示す. 気泡の捕捉原理は, 微小スリットに気泡が浸入する時の気泡が形状変化し, 表面エ ネルギーが変化することによるもので, これらの仕事が圧力よ って仕事されたとして, 次式で表された圧力差以下であるとき， 気泡が通過できなくなる.

\section{$\Delta \mathbf{P}=2 \gamma_{\mathrm{a}}(1 / \mathrm{w}+1 / \mathrm{h}-1 / \mathrm{W}-1 / \mathrm{H})$}

ここで $\gamma_{\mathrm{a}}$ は表面張力 $\left.\mathrm{N} / \mathrm{m}\right] て ゙, w, h, W, H$ はそれぞれ細い流路幅 深さ, 太い流路の幅と深さを示す. 狭いスリット幅 $14 \mu \mathrm{m}$, 深さ $78 \mu \mathrm{m}$, 広いスリット幅 $36 \mu \mathrm{m}$, 深さ $88 \mu \mathrm{m}$ のチャンネルによる 気泡除去実験を行った．実際に気泡を捕捉した画像を図 6(a)-(c) に示す. スリット幅以上のさまざまなサイズの気泡を捕捉でき ている. チャンネル入り口の圧力変化を図 6(d)に示す. スリッ 卜をふさいでしまった瞬間から圧力が増加し. 気泡は, 幅の広 いチャンネルからちぎれるようにして下流へ流れていき，その ときの圧力は减少した. その後捕捉された気泡により圧力が増 加していた. 気泡が通過した時圧力は, $5.55 \mathrm{kPa}$ となり幅の狭い スリットの理論值 $10.5 \mathrm{kPa}$ と幅の広いスリットの理論值 $3.9 \mathrm{kPa}$ との間の值になった. 理論値とは異なったものの, スリット幅 を設計することにより所望の圧力まで気泡を捕捉することが明 らかになった. 本研究で提案したスリットによる気泡の捕捉を 行う際には，流路全体をふさぐような大きな気泡には向かない が, スリット幅よりも大きく，スリットを完全に埋めない程度 の気泡の除去に有効であるといえる.

\section{3 気泡と気泡周りの流れの可視化計測}

図3に示した実験装置を用いて. 蛍光粒子 $510 \mathrm{~mm}$ をトレーサ粒 子と $460 \mathrm{~nm} \sim 490 \mathrm{~nm}$ の波長にフィルタリングされた水銀ランプ

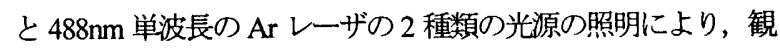
察を行った. 気泡周りの流れの観察には, 界面での散乱光が少 ない $\mathrm{Ar}$ を使用し. 気泡の挙動, 形状の観察には水銀ランプを光 源とした.

次に, 流速 $0.89 \mu \mathrm{m} / \mathrm{sec}$ のときの気泡周りのPIV 計測を図 7(a) に示した測定箇所について行った. 主流のX,気泡上面 $\mathrm{Y}$ とした

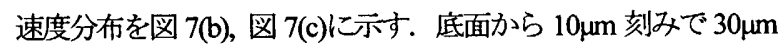
までの流れを解析した.気泡よりも上流の流れの PIV 結果から, 深さ方向の速度変化を見ることができなかったが，水平速度分 布について良好な解析結果を得ることができた. 気泡の観察可 能な倍率において，このような遅い流れではPIV 解析可能であ ったが，気泡脱離時の気泡周りの流速は速く，ICCD カメラの 性能の性能上, 流速約 $5 \mu \mathrm{m} / \mathrm{sec}$ までが限界であった.

\section{1 壁面からの脱離までの気泡の形状変化}

得られた画像から，気泡の脱離までの形状変化を画像相関法に より測定した. 得られた画像の気泡周囲に 7 点, 投影面積の気 泡の重心を G1，付着面積の重心をAG1 した測定箇所を図 8(b) に示す. AG1 と G1 間の流九方向の距離は気泡の変形を, al と a7 間距離は, 気泡の側面との付着長さを, al a8 で囲まれた投 影された気泡面積の変化を表し, 流量を増加させたときの時間 経過を図 8(c)に示す. 初期の状態からの変化を示す. 付着まで に, AG1 と G1 の距離が短くなっており, 側面との付着長さが 減少している. 気泡が壁面から脱離するとき, 付着面積が減少 し，気泡の変形が起こっていることが明らかになった。

3.2 シミュレーションによる気泡脱離時の変形解析

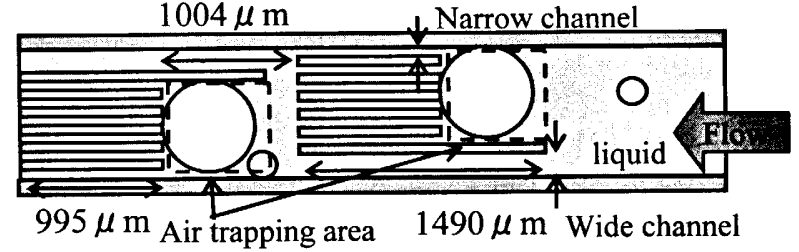

Fig.5 Schematic diagram of air removal channel

Table 1 Specification of air removal channels

\begin{tabular}{c|c|c}
\hline & Width $[\mu \mathrm{m}]$ & Depth $[\mu \mathrm{m}]$ \\
\hline Narrow channel & 12,23 & 77,85 \\
\hline Wide channel & 38,62 & 86,90 \\
\hline Section A & 1000 & 99 \\
\hline
\end{tabular}

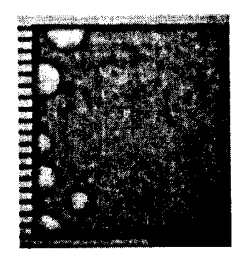

(a) Small bubbles(b) Middle bubbles

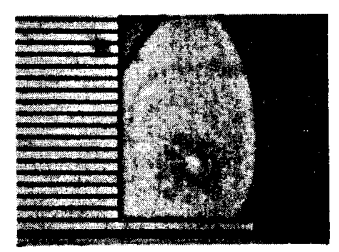

(c) Large bubble

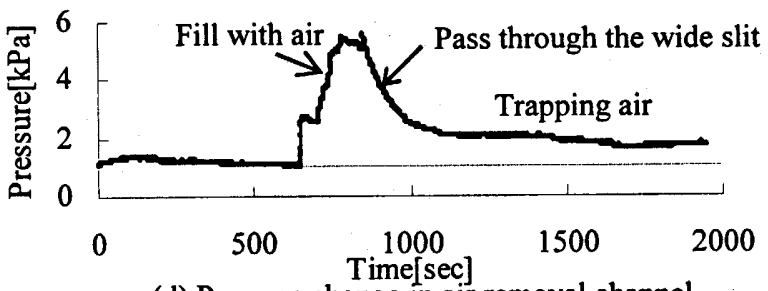

(d) Pressure change in air removal channel

Fig.6 Evaluation of air removal channel

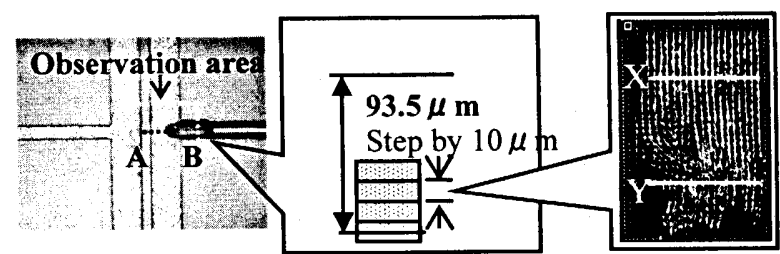

(a) Measurement section of velocity distribution

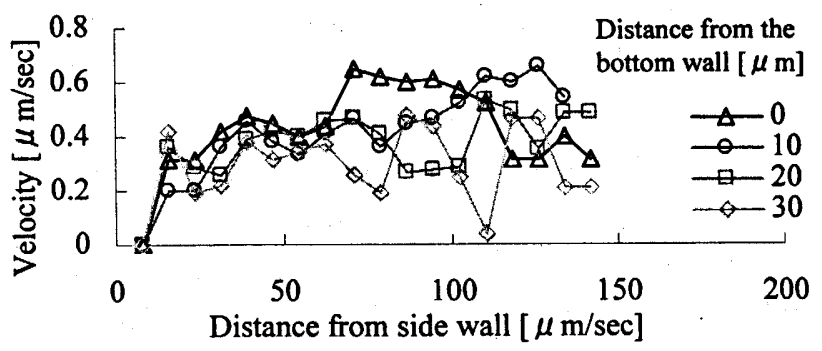

(b) Velocity distribution at section $\mathrm{X}$

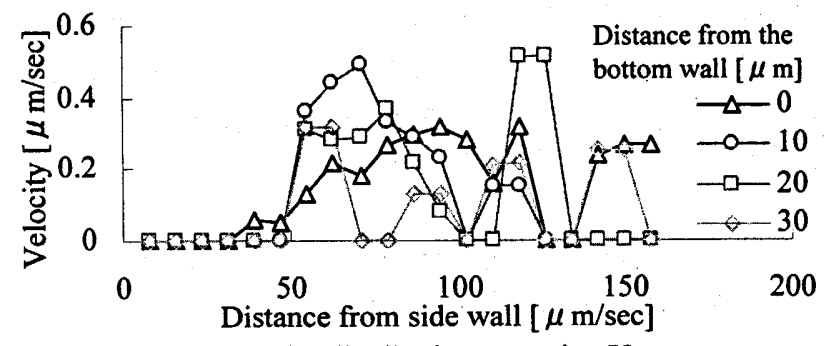

(c) Velocity distribution at section $\mathrm{Y}$

Fig.7 Velocity distribution of section $\mathrm{X}$ and $\mathrm{Y}$ 
自由表面である気液界面をシミュレーション可能な Volume of fluid(VOF)法を用いて気泡脱離シミュレーションを行った. VOF 法とは，計算を行うセルの液体充填率を VOF 值として設定する ことで，気体と液体の界面を表現するものである. 图 9(a)(b)に 使用したモデルを示し, 図 9(c)k解析結果を示す. 気泡の変形 とともに，圧力や流速の分布を明らかにした，脱離時には，流 れ上流から固気界面が減少し, 気液界面が変形, 界面からちぎ れるように脱離した，最終的な脱離侍の挙動は異なったが，脱 離までのプロセスは実験によって観察された結果と同様となっ た.

\section{4 気泡の特性評価}

\section{1 本研究における付着の分類}

4 種類に分類した気泡の付着形態を図 10 に示す，本研究ではパ ターン1 とパターン4を中心に観察を行った.

図3に示した実験装置で気泡の脱離実験を行った. 生成した気 泡が, $1 \mu / \mathrm{min}$ で流されす固液界面を持っているとき付着してい るとみなし, 流速を増加させていき, 気泡の脱離までの過程を 録画した.

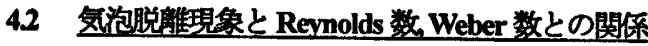

粘性力に対する慣性力の大きさを表す Re と表面張力に対する 慣性力の大きさを表すWe の 2 種類によって気泡脱離現象の評 価を行った. Re とWeはそれぞれ炏式で表される.

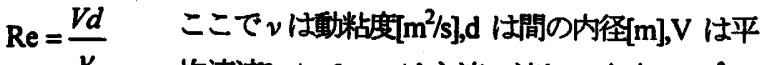

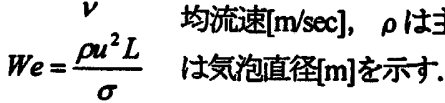

$\operatorname{Re}$ 数と気泡直径との関係を図 $11, \mathrm{We}$ 数と気泡直径の関㐿を図 12 に示す.We 数の気泡まわりの流速は，気泡の断面積を除い た流路断面積によって計算される平均流速を用いた。

気泡直径の堿少にともない，Re 数が増加していることから， 脱離させるエネルギーが増加しており，小さな気泡は流れによ って脱離しにくいといえる. また, We 数と気泡直径との関係で は，気泡の付着形態によって異なる傾向を示し，パターン 1 で は気泡直径の減少にともない, We 数が減少し, パターン4 の気 泡では，流路深さを境に逆の結果を示した．以上から，パター ン1の気泡は径の減少にともない表面張力が支配的になり，付 着形態がパターン 4 になると，上下の壁面が気液界面でつなが り，表面張力の影響があらわれるようと考えられる．また，本 実験では，最後まで脱離せず夜中へ解けこんでしまう気泡が観 察された. 気泡直径の時間経過を図 13 に示す. 流速が增加する につれて, 気泡直径の減少速度は増加している. また, 気泡直 径か減少するにつれて，消失速度は增加する傾向をしめした。

\section{5 エネルキーモデルによる付着，脱離現象の評価}

流路内における気泡の取る状態が，表面自由エネルギー最小の 状態を取ると仮定したモデルを用いて，気泡の付着と脱離現象 について評価を行った. 付着形態をパターン1に限定した時の, 流路内の付着状態とエネルギー状態を図 14 に示す.

$\mathrm{E}_{\mathrm{a}}$ : 気液界面のみで囲まれた球形の気泡のエネルギー $\mathrm{E}_{\mathrm{a}}=\mathrm{A}_{\mathrm{a}} \mathrm{yad}$ $\mathrm{E}_{\mathrm{b}}$ : 気液界面と固気界面で囲まれて壁面に付着している気泡の エネルキ $E_{b}=\left(A_{a}+A_{d y} \cos \theta\right) / a$

$\mathrm{E}_{b^{\prime}}: \mathrm{b}$ と同様の形状で, 気液界面のみで囲まれている気泡のエ
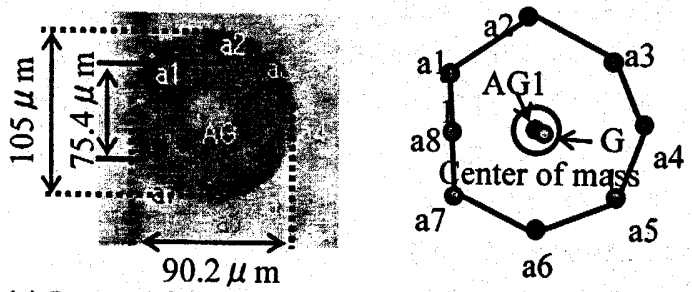

(a) Image of a primal air (b) Measurement points of an bubble air bubble

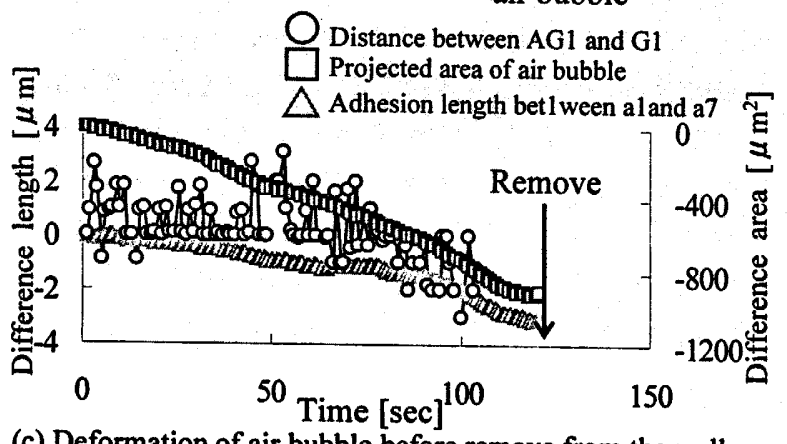

(c) Deformation of air bubble before remove from the wall Fig.8 Deformation of air bubble

Size of area

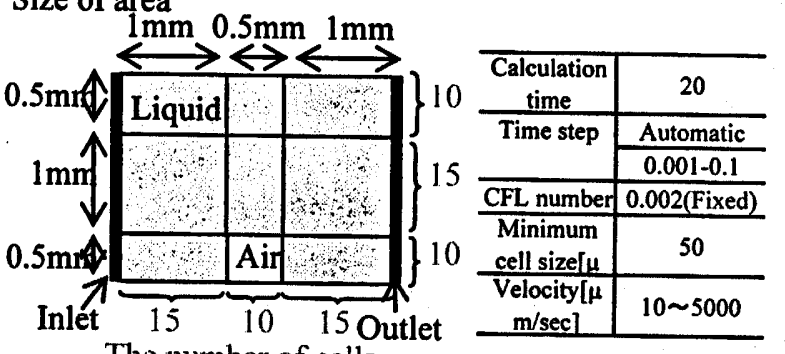

The number of cells (a) Simulation model

(b) Simulation parameters

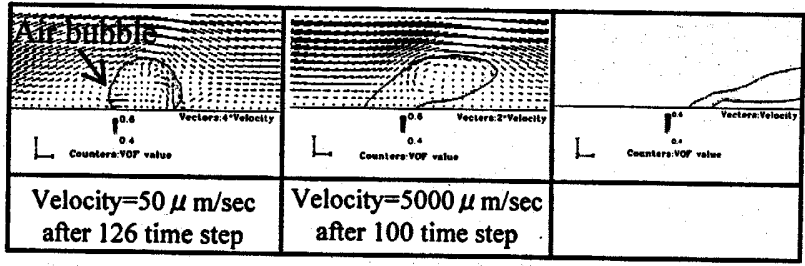

(c) Simulation results

Fig. 9 Air removal simulation

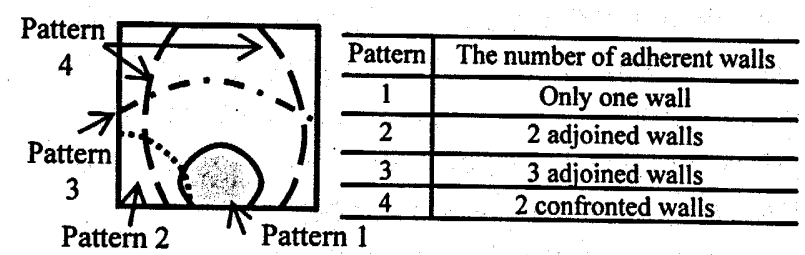

Fig. 10 Adhesion pattern

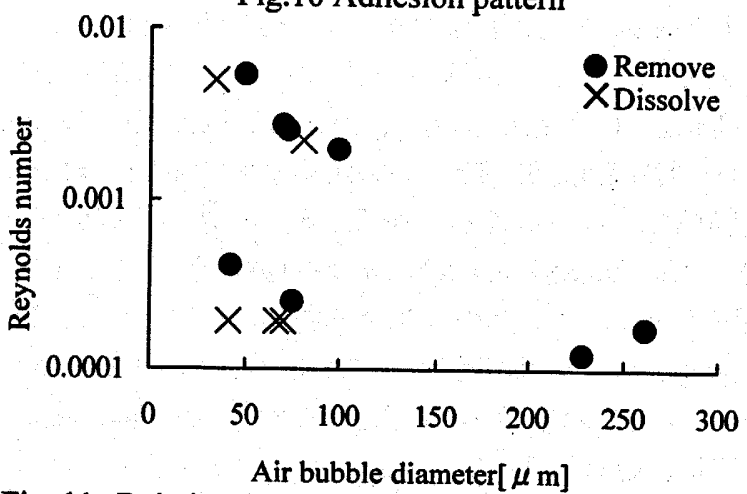

Fig. 11 Relationship between Reynolds number and air bubble diameter 
ネルギ $\mathrm{E}_{\mathrm{b}}=\left(\mathrm{A}_{\mathrm{a}}+\mathrm{A}_{\mathrm{dy}}\right) \gamma_{\mathrm{al}}$

と表すことができる.ここで， $A_{a l}$ は気液界面の面積 $A_{d y}$ は固液 界面の面積を表す．また， $\mathrm{L}=(\mathrm{V})^{1 / 3}$ と定義した気泡長さで整理 する. 付着と脱離はエネルギーの遷移で考えると次のように表 すことができる.

付着 : a から b’を経て, b 状態へ遷移すること

脱離 : $\mathrm{b}$ の状態から b'を経て $\mathrm{a}$ の状態へ遷移すること

付着のためのエネルギー : $\mathrm{E}_{\text {Adhesion }}=\mathrm{E}_{\mathrm{b}}-\mathrm{E}_{\mathrm{a}}$

脱離のためのエネルギー : $\mathrm{E}_{\text {Remve }}=\mathrm{E}_{\mathrm{b}}-\mathrm{E}_{\mathrm{b}}$

単位体積あたりの $\mathrm{E}_{\text {Adhesion }}-\mathrm{E}_{\text {Reme }}$ と接触角，気泡長さの関係を 図 15 に示す. 気泡の径によっても変化するが, 接触角が約 $70^{\circ}$ を境にして， $\mathrm{E}_{\text {Adhesiom }}$ と $\mathrm{E}_{\text {Rermve }}$ 入れ替わる. $70^{\circ}$ 以下では脱離つ゚ ロセスが優先的に起こり，70 以上では，付着が優先的に起こ るといえる。

次に，エネルギーがひずみとして脱離が起こるまで蓄えられ ると仮定する. 単位体積あたりのエネルギーは

$\mathrm{U}=\mathrm{F}^{2} /\left\{2 \mathrm{~A}^{2} \mathrm{G}\right\}$ と表すことができる. ここでは，F が気泡に加わる 力, $\mathrm{A}$ が流れ方向と平行な面に投影した気泡の断面積, $\mathrm{G}$ が気 泡の横弾性係数を表す。

変形した気泡の曲率半径の分布によって変形した気泡はもと の形状に戻ろうとする，変化した気液界面の曲率によって生ま れるラプラス圧が気泡のひずみに線形であるとした.このエネ ルギーがエネルギーモデルによって評価した脱離条件である E るためには，以下パラメータに関係する物理量を変化させれば よいといえる.

F を増やす : 流速を増やす, 粘度をあげる

A を減らす : 接触角を減少させる

G を減らす: 気泡を合体させて大きくする，もしくは，減圧し 気泡を膨張させる。

\section{Micro fluidic device $の$ 設計指針}

本研究の結果から得られた気泡の付着と脱離特性から, 以下の 項目を改善すればよい.

流体と壁面との濡れ性 : 脱離には，最低接触角が $70^{\circ}$ 以下. 付 着させるときには $70^{\circ}$ 以上が好ましい!

流路形状 : 断面が正方形もしくは円形

送液方法 : 減王による送液

気泡除去 : 長時間ながすことで夜中に溶け込ませる

気泡除去チャンネル : スリット幅と同等の気泡が付着し気泡脱 離が起こらない流速かつ，脱離する気泡が変形し通過しない压 カとなる流速となるように流路を設計.

\section{7 結言}

本研究では，流路内部の気泡の状態分類し，表面自由エネルキ 一によって評価することで, 気泡の付着と脱離要因を明らかに し， $\mu$ 流体デバイスの設計指針を提案した.

\section{8 参考文献}

[1]S.T.Wereley, N.T..Nyryen, Fundamental and Application of Microfluidics, Artech House.

2]L.W.Scheart On the motion of bubble in capillary tubes, JFluid Mech.vol172, 259-275

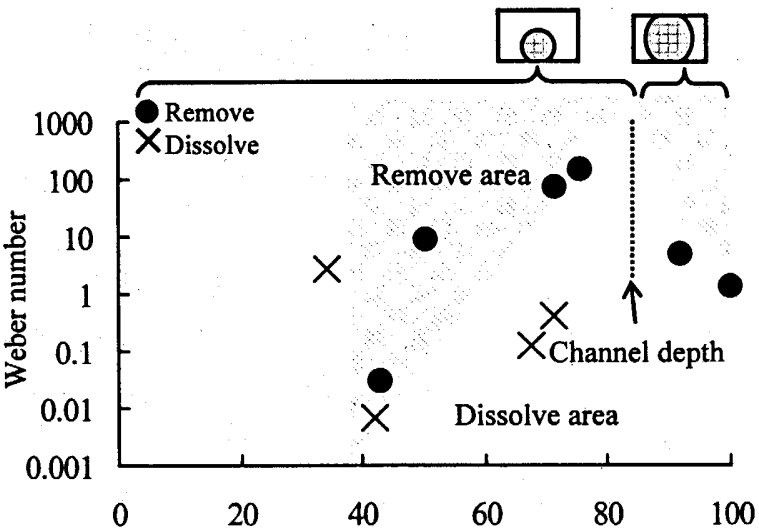

Fig. 12 Relationship between Weber number and air bubble diameter

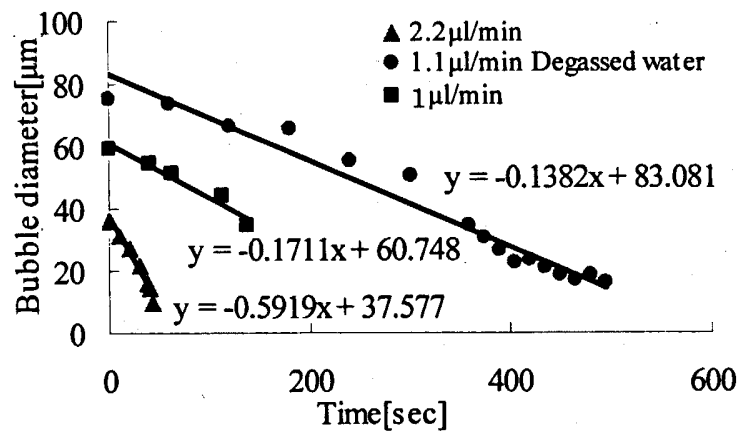

Fig.13 Diameter change of air bubble dissolve into water

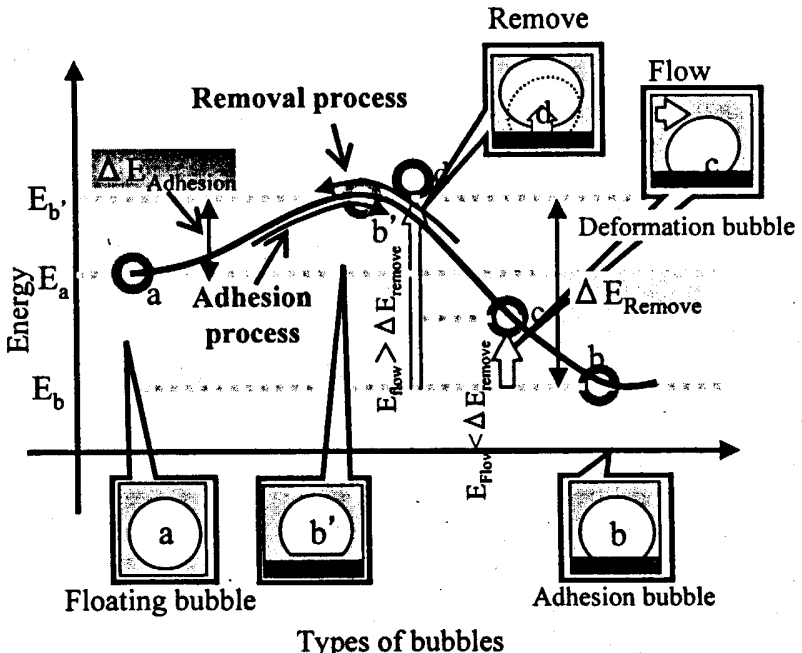

Fig. 14 Energy condition at several air bubble types

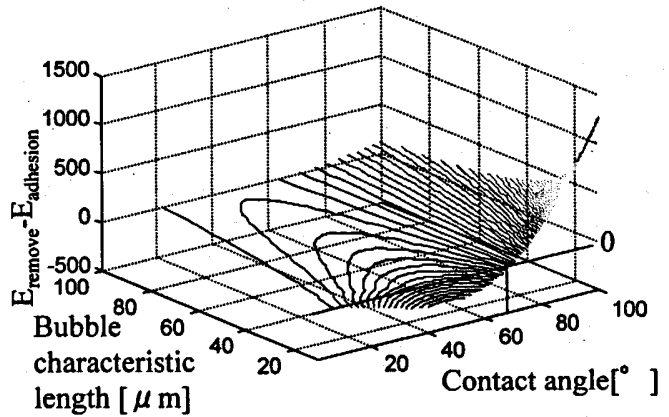

Fig.15 Relationship among $\mathrm{E}_{\text {remove }}-\mathrm{E}_{\text {adhesion, }}$, Bubble characteristic length , and contact angle 